\title{
Pedagogy of social transformation in the Hebrew Bible: Allowing Scripture to inform our interpretive strategy for contemporary application
}

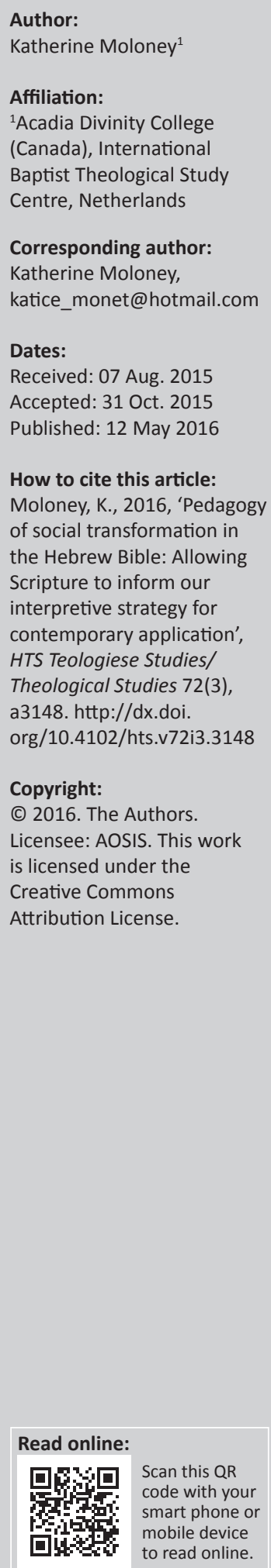

\begin{abstract}
The Hebrew Bible itself teaches its readers and listeners how to learn. Its pedagogy of social transformation instructs contemporary Christians how to interpret and apply lessons from Scripture in a manner that is consistent with the orientation, priorities and methods inherent in the text. This article demonstrates that relationship and identity are the necessary precursors to biblical education. It then considers the educational perspective for social transformation within the Hebrew Bible. The analysis explores the purpose and process of education for social transformation and the pastorally oriented pedagogy that the Bible utilises to advance moral development and prevent hermeneutic bias. Lastly, the article considers how the narrative, Law, prophets and wisdom texts in the Hebrew Bible train in social critique. This article helps Christians to develop a biblically based hermeneutic of the Hebrew Scripture's social transformation for application today.
\end{abstract}

The banyan tree has been likened to Hinduism in that it is 'microcosmically polycentric, macroscopically one' (Kim 2004:44). The same metaphor could similarly be applied with reference to the unity of the Hebrew Bible despite its marked diversity. It is precisely by virtue of its complexity and heterogeneity that the works therein are able to be of relevance across the plurality of human contexts and conditions, experiences and emotions. Yet, for the Hebrew Bible to aptly inform social transformation in a contemporary setting, it is necessary to develop a comprehensive, rigorous and practicable interpretive strategy.

This article posits that the Hebrew Bible itself teaches its readers and listeners how to understand, analyse and apply the Word. It further contends that careful investigation into the intrinsic means by which the Hebrew Scripture teaches is pertinent to biblical hermeneutics, providing practical tools to aid present-day appropriation as regards social transformation. Indeed, '[a]ll Scripture is God-breathed and is useful for teaching, rebuking, correcting and training in righteousness, so that the servant of God may be thoroughly equipped for every good work' (2 Tim. 3:16-17). ${ }^{1}$ This article thus assumes the contemporary pedagogical significance of the Hebrew Bible in its entirety, and its authority, validity and utility in preparing the Christian community to live the Bible's moral instruction today.

The Hebrew Bible itself endows the church with the means by which to conceive of God and his creation and to interpret, evaluate and apply these lessons in a manner that is consistent with the orientation, priorities and methods inherent in the text. An appreciation of its pedagogy assists contemporary Christians to ask the 'right' questions and thereby reach beyond a shallow or selective hermeneutic that merely confirms preconceptions and priorities whilst omitting the weightier matters that the Hebrew Bible teaches.

\section{First things first}

\section{Relationship and identity as precursors to education}

\section{The Divine Teacher}

Good and upright is the LORD;

therefore he instructs sinners in his ways.

He guides the humble in what is right

he teaches them his way. (Ps. 25:8-9) 
First and foremost is God. He is the Divine Teacher who, through all divine persons of the economic Trinity and as recorded in all biblical genres, undertakes a continuous and integrated plan of holistic education with a set purpose and process (Colless 1970:140-141). YHWH is unlike any other teacher (Job 36:22) for he is good and upright (Ps. 25:8). His way and commandments are perfect (2 Sam. 22:31).

YHWH's teaching is grounded in humanity's relationship with and identity in him. These necessarily precede further instruction. Yet to discern the diverse and dynamic representations of relationship and identity that span the Hebrew Bible requires close examination. Although such a comprehensive analysis is beyond the scope of this article, by way of example, below are two brief studies that consider selected symbols and stories depicting, respectively, the words and deeds of God.

\section{Wife: Relational fidelity}

I [the LORD] will betroth you [Israel] to me forever;

I will betroth you in righteousness and justice,

in love and compassion.

I will betroth you in faithfulness,

and you will know the LORD. (Hos. 2:19-20)

Israel's relationship with her God is powerfully conceptualised in terms of a marriage in prophetic metaphor. The interpretive complexities of the covenant relationship become instantly accessible with symbolic representation. This literary device succinctly captures the tender intimacy of God's faithful love or, conversely, viscerally portrays his deep anguish at Israel's betrayals (e.g. Ezek. 16).

From this illustrative example can be gleaned an insight into YHWH's desire for covenantal integrity, to which may be added the innumerable perspectives on the Divine-human relationship that permeate the Word. ${ }^{2}$ Thus, it may be observed that $\mathrm{YHWH}$ is the initiator of the covenant relationship; it is on his very attributes that the relationship is built. Moreover, a principle desire is that he be intimately known by his people.

The marriage metaphor expresses the exclusivity and centrality with which God's people are to regard him. He is indeed gracious and compassionate, slow to anger and abounding in love (e.g. Exod. 34:6; Joel 2:13). Yet he is also holy and requires singular devotion (Hos. 2:2-13). Therefore, although there are consequences for errant behaviour, there is also forgiveness (Hos. 2:14-23):

Yahweh acted as a patient educator, instructing and correcting, showing his wrath when the pupils were refractory in their behaviour, yet always ready to restore a right relationship so that the education procees [sic] could continue. (Colless 1970:140)

A hermeneutic for contemporary social praxis ought to recognise the primacy of one's relationship with $\mathrm{YHWH}$ and the obligation to act in a manner that conforms to and is consistent with the values of the covenant relationship. Furthermore, the importance given to relational integrity in the Hebrew Bible implies that it is relationship that comes first, in sequence and priority, before any social (or otherwise) pursuit or programme.

\section{Slave and sojourner: identity formation}

God sees the misery of the afflicted, hears the cries of the enslaved. He intimately knows their suffering (Exod. 3:7). He redeems a people burdened under the yoke of slavery. The Exodus event, influencing a range of the Hebrew Bible's literary genres with multivocality, represents a dominant theme within the Israelite's collective memory. The narrative account of their dramatic political, economic, social and spiritual emancipation from Egypt has, for instance, been profitably expressed in terms of its importance as a redemptive paradigm (Wright 2006:265-288). Certainly, the Decalogue is prefaced by the declaration of YHWH's redemptive action on behalf of his people (Exod. 20:2; Deut. 5:6). In point of fact, the Hebrew Bible seizes upon this paradigm to great effect within Mosaic Law, strongly espousing it as prototypical for a primary Israelite identification with vulnerable and oppressed members of the community: slaves, sojourners, widows and orphans.

Nasuti (1986) demonstrates that embedded within the Pentateuchal laws are identity prescriptions - motive clauses and coordinate commands that impel positive action whilst specifying an identity as former sojourners and slaves. ${ }^{3} \mathrm{He}$ further affirms that the Law advances identification with and imitation of God (e.g. Deut. 10:18-19, 15:14-15) to the extent that he identified with and acted on behalf of the sojourner and the slave (Nasuti 1986:16-18). Such identification and imitation delicately and deliberately weave narrative ethics into deontology and have significant implications for interpretation and application:

The hermeneutical importance of biblical law lies in its ability to set up a dialectic of praxis and interpretation with identity as a crucial middle term. The ... laws specify both an identity and the praxis by which such an identity is constituted and maintained. As such, the laws work to provide the reader with a specified entry into the wider biblical text. (Nasuti 1986:19)

By heeding the direction therein, the Pentateuch schools its readers in the correct orientation by which to interpret and apply the Law as the author(s) intended. Mosaic Law does not seek an unmitigated obedience to the letter of the law as a minimum standard to which one must comply. Rather, it implores its readers and hearers to form their very identity on love for and obedience to YHWH (Deut. 11) as an ardent response to the redemptive grace first shown them. The extent to which this holistic redemption (political, economic, social and spiritual) is appropriated as identity is the degree to which true social transformation may occur.

3.Sojourners: Exod. 22:21, 23:9; Lev. 19:34; Deut. 10:19, 23:7. Slaves: Deut. 5:15, 15:15, 6:12, 24:18,22. 


\section{The educational perspective for social transformation in the Hebrew Bible}

\section{The scriptural purpose and process of education}

\section{The purpose of education}

Education for social transformation is at the heart of God's purposeful actions throughout history. To be sure, YHWH says of Abraham:

For I have chosen him, so that he will direct his children and his household after him to keep the way of the LORD by doing what is right and just, so that the LORD will bring about for Abraham what he has promised him. (Gen. 18:19)

The intimate covenantal relationship between God and his people requires their instruction in 'the way of $\mathrm{YHWH}^{\prime}$, the pursuit of righteousness and justice, which are the very characteristics of God (e.g. Ps. 89:14). 'In the structure as well as the theology of this verse, ethics stands as the middle term between election and mission' and represents both the 'purpose of election' and the 'means to mission' (Wright 2004:50).

In this passage, God enunciates his statement of purpose for education, namely to direct (lit. give charge to) the people of God that they may abide in him, keeping the way of YHWH. God's election of Israel, through his selection of Abraham and Sarah, has as its purpose training in ethical distinctiveness, which in turn finds its purpose in being the agent of blessing for the nations (Gen. 12:2-3, 18:18, 22:17-18). The enduring significance of education for God's purpose is reasserted in the New Testament through the Great Commission, whereby Jesus' divine directive requires making disciples (lit. pupils or adherents) and teaching the way of Christ (Matt. 28:19-20). Any interpretation and application of biblical social transformation needs to comprehend that the doing of that which is just and right is salient for God's missional purpose (see, e.g. Matt. 5:14-16). Therefore, social transformation ought always to retain the blessing of others as its objective, of both Christians and non-Christians.

\section{The process of education}

Proverbs 2 elucidates the principles and processes of education in the Hebrew Bible (Fox 1994). The text affirms that relationship (with God, v. 6, and with other people, v. 1) is a requisite for learning and is indelibly paired with the active participation of the learner (vv. 1-4). The educational process, as articulated in this lesson, commences with knowledge acquisition, with the learner heeding the words of the teacher (v. 1) and seeking wisdom (v. 4). The twofold outcome of the learning endeavour is:

1. reverence and knowledge of God (v. 5); such wisdom is bestowed by YHWH (v. 6)

2. discernment of 'righteousness, justice and equality - every good path' (v. 9); such wisdom is internalised (v. 10).

This, in turn, begets good and righteous behaviour (v. 20).
Reverence and awe of YHWH is the necessary precondition for obtaining wisdom (Prov. 1:7, 9:10), for it is assuredly God who grants wisdom (Prov. 2:6). The active learning process involves the learner's adherence to the tutelage of an elder in the faith (v. 1) and an increasingly invested pursuance of understanding (i.e. applying one's heart to (v. 2), calling out for (twice in v. 3) and seeking (twice in v. 4) understanding). The apex of the educational process, according to the Hebrew Bible, is obtaining intimate knowledge and discernment of God and of his character. This wisdom is appropriated into the learner's very heart for the purpose that it be enacted in a lifestyle that keeps the way of God's character (cf. Gen. 19:19; Jer. 9:23-24, 22:15-16).

The Hebrew Bible's process of education is thus the considered and committed undertaking of God, the teacher and the student. It is wholly relational. Moreover, the process actively transforms both orthodoxy and orthopraxy. This dyad is inextricably intertwined; one engenders the other. Thus, the Hebrew Bible assumes a holistic, all-of-life approach to education. Striving to understand God necessarily involves theology and ethics because to know God is to know his character and actions. And to know his justice and righteousness is to appropriate these, both cognitively and behaviourally, to the extent that it is possible. Furthermore, it may be argued that the practice of walking or keeping the way of $\mathrm{YHWH}$ is itself an enduring and encompassing educational process.

A case in point, Mosaic Law does not compartmentalise social, civil and ceremonial concerns. Dictates pertaining to each are interlaced dynamically within the text to form an integrated whole, over which God assumes lordship. For this reason, interpreting laws by imposing categories extrinsic to the text renders the interpretation inconsistent with the internal Israelite perspective (Wright 1992:229). Such categories are artificial in that the text does not distinguish or reduce the Law by segregating worship and ethics, personal and public spheres and so forth.

With respect to the New Testament, the principal educational method employed is discipleship, defined by Collinson (2006) as:

\begin{abstract}
an intentional, largely informal learning activity. It involves two or a small group of individuals, who typically function within a larger nurturing community and hold to the same beliefs. Each makes a voluntary commitment to the other/s to form close personal relationships for an extended period of time, in order that those who at a particular time are perceived as having superior knowledge and/or skills will attempt to cause learning to take place in the lives of others who seek their help. Christian discipling is intended to result in each becoming an active follower of Jesus and a participant in his mission to the world. (p. 164; italics in original)
\end{abstract}

There is a notably significant correlation between the educational process elucidated within the Hebrew Bible (as expressed in Prov. 2) and the means of Jesus' discipleship. This enhances the case for the abiding relevance of this process. One difference between the two processes is that all disciples, by definition, are required to assume the position of learner whilst also teaching the way of Christ (Matt. 28:20), 
whereas it is parental instruction that is prescribed in the Hebrew Bible (e.g. Gen. 18:19; Deut. 4:9-10, 6:7; Prov. 2:1).

Therefore, appreciating the nature of the educational process as exemplified in Scripture can further contemporary interpretation and application as regards the process of social transformation. The Word conceives of the educational process at the level of individual transformation and recognises the whole-of-life development that this entails. Biblically based social transformation is, in essence, a broadening of this model so as to effect change at the community level. Thus, when conceived as paradigmatic, this transformative process at a societal level elevates and empowers the beneficiaries from mere passive recipient status to active and willing participation in a process. In this manner, all stakeholders participate as 'colearners', contributing to a common goal. The Christian may provide specialist knowledge grounded in biblical truth, yet a determining factor of social transformation is the degree to which the beneficiary takes ownership in directing the process, for it is this commitment that will sustain its continuance. Importantly, social transformation is axiomatically holistic. And it is ultimately God who bestows it.

\section{Pastorally oriented pedagogy}

\section{Led with the cords of human kindness}

There exists throughout the written Word a dynamic tension between the Kingdom ideal and the reality of moral praxis in a world marred by sin. The Kingdom ideal is deftly embedded in and interlaced throughout Scripture. Yet preeminent is a pastorally oriented pedagogy expounding practical instruction for moral application that is sensitive to humanity's sinfulness and the particular historical-cultural context. This stepwise tutelage, similar to instructional scaffolding, ${ }^{4}$ reflects the graciousness of a God who stoops low to raise up his people. He accepts their human condition whilst ever leading them in the way of YHWH towards his Kingdom ideal (cf. Ps. 25:8-10). The Torah (and indeed the other texts of the Hebrew Bible) 'attempts to anticipate that [eschatological Kingdom] ideal in the circumstances of ancient Near Eastern society, which requires not only cultural specificity but also compromise' (Bauckham 2011:29). Goldingay (1987:134-166) sagaciously describes this condescension whereby Kingdom ideals are by necessity compromised in order that social praxis be both feasible (amidst sin and in context) and subject to YHWH.

Likening God's instruction to the loving intimacy with which a parent takes a small child by the hands to teach him to walk, Hosea 11:3-4 illustrates the dedication with which God disciples, challenges and grows his people, incrementally building them to maturity in him. To extend the analogy, it is possible to visualise the enactment of this pastoral strategy, tiny supported steps juxtaposed with erroneous stumbling, spanning the history of both Testaments. Although the infant's precision undoubtedly develops by way of repeated

4.Instructional scaffolding is an educational strategy of supported learning to build and construct knowledge with the purpose of enabling the development of and construct knowledge with the purpose of enabling the development of
independent learning strategies. This concept was described in Wood, Bruner \& independent learnin
Ross (1976:89-100). faltering, his is by no means a linear trajectory of development (cf. Jer. 32:33). Furthermore, the child's learning requires the attentive guidance of the faithful parent on whom he must rely. Indeed, YHWH's pastoral strategy denotes a committed long-term relationship in which he is heavily invested. He thus distinguishes between the person and his or her behaviour such that the former is accepted whilst the latter only partially so and only to the extent that it facilitates transformation. Highlighting the merit in building enduring relationships, God's pastoral strategy endeavours to transform by engaging a people at their level.

\section{Stages of moral development}

The Hebrew Bible's pastoral strategy makes an appeal to all levels of moral reasoning. This differentiated instruction has the objective of ethical maturation in the direction of internalised morality based on the knowledge of God, inscribing the Law onto one's heart (Deut. 6:6; Jer. 31:33). With reference to Kohlberg's stages of moral development (see, e.g. Kohlberg 1981), it is apparent that the Hebrew Bible responds to an egocentric, externalised pre-Conventional morality by prescribing specific concrete directives that are foundational for establishing God's expectations of ethical distinctiveness. These deontological standards are oriented towards obedience of rules, avoidance of punishment and recognition of selfinterest in moral decision-making (Kohlberg's Stages 1 and 2).

The Hebrew Bible augments its teaching to incorporate the increasing sensibility to interpersonal and societal relationships in Conventional morality. In so doing, it proffers a societal framework that is at once clearly defined whilst also being responsive to one's dynamic interactions with God, kin, community and creation. Thus, emphasis is placed on the merit of interpersonal accord, conformity to social roles and adherence to authority in order to maintain social functioning (Kohlberg's Stages 3 and 4).

Finally, with a strong grounding in the foundations and framework of God's moral instruction, the Hebrew Bible calls for faithful appropriation of relational integrity in accordance with the characteristics of the living God. Post-Conventional morality thus requires considerable ethical maturation, which engenders careful discernment and, where necessary, independent abstract reasoning. The Hebrew Bible promotes fidelity to social contracts, such as covenant and marriage, and internalisation and application of God's characteristics, for example, his justice, righteousness, mercy and holiness (Kohlberg's Stages 5-6 and the hypothesised Stage 7).

For the purpose of illustration, Table 1 provides a narrow sampling of the means by which the Hebrew Bible makes an appeal to all stages of moral development. Certainly there is limited utility in assigning moral stages to particular verses beyond that of appreciating the complexity of the moral instruction present in Scripture. The Hebrew Bible seamlessly interweaves various types of moral reasoning alongside one another in a given text. Such is the case in the book of 


\begin{tabular}{|c|c|c|}
\hline Kohlberg's Stage & Appeal & Examples \\
\hline \multicolumn{3}{|l|}{ Pre-Conventional morality } \\
\hline Stage 1: Obedience and punishment orientation & $\begin{array}{l}\text { - absolute moral directives } \\
\text { - warnings } \\
\text { - discipline/punishment } \\
\text { - curses }\end{array}$ & $\begin{array}{l}\text { Gen. 2:16-17; Ex. 20:3-17 } \\
\text { Isa. 3; Jon. 3:4 } \\
\text { Lev. 20; Neh. 13:25; Prov. 18:6; Lam. 1:18 } \\
\text { Deut. 27:15-26, 28:15-68; Mal. 2:2 }\end{array}$ \\
\hline Stage 2: Self-interest orientation & $\begin{array}{l}\text { - promise of rewards and blessings } \\
\text { - illustrations of the repercussions of self-interest }\end{array}$ & $\begin{array}{l}\text { Deut. 28:1-14; Zech. 8:14-7 } \\
\text { Gen. 20; Josh. 7:26; Judg. 19:25 }\end{array}$ \\
\hline \multicolumn{3}{|l|}{ Conventional morality } \\
\hline Stage 3: Interpersonal accord and conformity orientation & $\begin{array}{l}\text { - approval } \\
\text { - renown } \\
\text { - avoid reproach, shame }\end{array}$ & $\begin{array}{l}\text { Prov. 3:4, 10:1, 16:13 } \\
\text { Deut. 4:5-6; Josh. 3:7-13 } \\
\text { Deut. 25:5-10; Neh. 5:9 }\end{array}$ \\
\hline $\begin{array}{l}\text { Stage 4: Authority and social order maintaining } \\
\text { orientation }\end{array}$ & - maintaining social structures and distinctiveness & $\begin{array}{l}\text { Num. 27:8-11, 36:7-9; Deut. 13:5, 17:8-13, 23:1-8; } \\
\text { Judg. 20:13 }\end{array}$ \\
\hline \multicolumn{3}{|l|}{ Post-Conventional morality } \\
\hline Stage 5: Social contract orientation & $\begin{array}{l}\text { - covenant relationship } \\
\text { - marriage fidelity } \\
\text { - majority decision }\end{array}$ & $\begin{array}{l}\text { Gen. 22; Deut. 10:12-14 } \\
\text { Gen. 2:24; Prov. 5:15-19 } \\
\text { Judg. 20:8-11; Neh. 9-10; Hag. } 1\end{array}$ \\
\hline
\end{tabular}

Nehemiah, whereby Nehemiah's persistent refrain appealing for God's favour (Kohlberg's Stage 3 reasoning) is matched by a genuine concern for the glory of God and the welfare of his people (post-Conventional morality). Furthermore, whilst the Torah is more heavily weighted in favour of concrete specificity for practical purport, it contains the breadth of moral reasoning. Indeed, it contains the greatest commandment of love for God (Deut. 6:4-5, 11:13; cf. Matt. 19:19, 22:37-38; Mark 12:28-30; Luke 10:27-28) and neighbour (Lev. 19:18,34; cf. Matt. 7:12, 22:39-40; Mark 12:31; Luke 10:27-37; Rom. 13:8-10; Gal. 5:14). The brilliance of the Hebrew Bible thus includes the way in which it masterfully and dynamically interplays the spectrum of moral reasoning, both within a particular text and throughout the Hebrew Bible as a whole.

\section{The breadth of human experience}

Indeed, YHWH's perfect ethical theory, or Kingdom ideal, is ever constant. His pastoral strategy is dynamic and responsive in its instruction for moral practice. God refrains from challenging and correcting all sinfulness at once because humanity's hardness of heart precludes the realisation of a once-and-for-all sanctification ahead of the eschatological Kingdom. Yet traversing the Bible's metanarrative, at each stage of the journey, the people of God need to hear a particular message that illuminates and instructs in a particular manner. Each individual book of the Old (and New) Testament gives prominence to that which is contextually pertinent, the aggregate of which, when considered within the whole canon, addresses the fullness and complexities of life and builds up a holistic and dynamic theology.

The Word avails itself of the myriad life experiences and emotions that find expression in the text to draw forth instruction on life with God and his creation in its multiplicity. A case in point is the spectrum of human emotions expounded upon by the psalter, whose deeply passionate and intimate prayers model how to pray. Although to each person at each stage of life a particular passage may be apposite, the breadth and heterogeneity of material in the Hebrew Bible propounds, indeed promotes, an appreciation of and empathy for others in their respective contexts. In so doing, it broadens the minds of its readers and listeners beyond an insular self-concern.

Consequently, it is untenable to derive an interpretative strategy based on a particular book or genre to the exclusion of others. Although, for instance, the Torah contains enforceable (by virtue of prescribed sanctions) precepts, it is misguided to assume that the values expressed therein take precedence over the stark critique of the prophets, the realworld examples contained within the narrative and Wisdom Literature's teachings about God and virtue. For in as much as the relevance of each book is advanced by a theological orientation and form that is responsive to the historicalcultural context at the time of authorship, it is this specificity that also constrains the universality of its message. All the books of the Hebrew Bible have the authority of Scripture, yet each one is incomplete in and of itself. A 'fuller understanding' of the Hebrew Bible, argues Goldingay (1987:112), 'ultimately involves the attempt to do justice to the material as a whole, understood and evaluated on the basis of interconnections and priorities suggested by the material itself'.

The Hebrew Bible itself thus provides in-built regulatory mechanisms in support of a rigorous and comprehensive interpretive analysis for practical application of the Kingdom ideal. Moreover, it affords a corrective gauge to help guard against hermeneutic bias. For example, an appreciation of the fullness of God's moral instruction embedded within and throughout the Hebrew Bible discourages a disproportionate focus on the Law and a tendency towards legalism. Similarly, by correctly orienting ourselves and considering the wholeof-life teaching of the pedagogy of the Hebrew Bible, we (the Christian community) are able to recognise and minimise the effects of the presuppositions and prejudices that circumscribe our knowledge of God.

\section{Training in social critique Narrative history}

The Bible may be construed in terms of an expansive narrative, or metanarrative, to which all individual Scriptural 
narratives belong and from which the church continues to dynamically derive its own narrative, the so-called storyformed community:

$[D]$ escriptively the self is best understood as a narrative, and normatively we require a narrative that will provide the skills appropriate to the conflicting loyalties and roles we necessarily confront in our existence. (Hauerwas 2010:144)

This metanarrative is one means by which to unify the various components, subplots and themes that enrich the living Word and inform a coherent hermeneutic.

Biblical narrative is a compilation of historiographical accounts that relay impassioned interpretative retellings of actual historical events. The inherent selectivity and focus of the narrative texts undergird their didactic purpose. The characters depicted within the narrative texts, even those chosen as God's instruments, are typically represented in all of their humanity - neither wholly good nor wholly bad but a complicated mix of virtue and frailty. Moreover, the texts invariably incorporate an in-built social critique that trains readers and listeners of the Hebrew Bible to actively question the status quo. Rarely does the narrative divulge explicit social comment, yet neither is the apparent neutrality of the text to be taken at face value. Rather, close attention to and critical reflection on the text invariably reveal a deliberate intimation and suggestive ambiguity to provoke careful exegesis (M.J. Evans, pers. comm., 31 October 2013). A case in point is the abhorrent offering up by Lot of his daughters to be violated by the occupants of Sodom in place of his male house guests (Gen. 19:7-8). However, the narrative recounts that the visitors commanded (v. 15) and physically compelled (v. 16) Lot (for the sake of Abraham, v. 29) as well as the female members of his household to flee to safety. By their discernible inclusion of Lot's wife and daughters through this protective measure, the angelic visitors and the author subtly affirm the value of women despite their overt depreciation by Lot. ${ }^{5}$

The narrative texts are thus intended to cultivate astute readers and listeners of the Word. The genre actively engages the people of God in a history that defies a superficial rendering. It challenges them to critique contemporary social norms in light of Kingdom ideals, and it equips them for such an analysis by subtle and sophisticated cues embedded in the text.

\section{The Law}

As has previously been noted, YHWH's gift of the Law for an elected and redeemed people is a dynamic teaching

5.By comparison, with regard to the similar case of the Levite and his concubine in Judges 19, Geisler (2010:291) comments, ' $[A]$ s horrible as the rape and consequent evil that followed, the Levite saw giving his concubine to them as a less "disgraceful thing" than homosexuality' (v. 24). This statement seriously misrepresents the narrative. Firstly, what is proposed by the owner of the house (and by Lot in Gen $19: 7-8$ ) is a substitute rape, of a female instead of a male. While this demonstrates the lesser value with which women were viewed in the cultural context, it is not comparison between rape and consensual homosexual sex. Indeed, it is not comparison between rape and consensual homosexual sex. Indeed, the Levite claimed that he believed his life to be at risk (Judg. 20:5). Secondly, the inference Geisler makes in this sentence is that, just as the elderly man valued a male strange over his virgin daughter and his guest's concubine and just as the Levite valued his physical integrity over that of his concubine, this societal value is representative of God's values. However, this period was notable for 'everyone [in Israel]' behaving 'as they saw fit' (Judg. 21:25). If Christians do not attend closely to the narrative, such grievous inferences may be espoused. device to instruct in the way of God's holiness (Exod. 19:4-6; Lev. 19:2, 20:7; cf. 1 Pet. 1:13-16, 2:5,9) for the blessing of the nations (Deut. 4:5-8). This call to ethical distinctiveness challenges the people of God to confront societal values and practices that are incongruent with the holiness of God, whether they be characteristic of the wider ANE cultures (e.g. Deut. 18:9) or of the currently held thoughts and behaviours of the people of God (e.g. Deut. 9:7-10, 22). To appreciate the extent to which Torah critiques and progresses social norms requires attentive historical-cultural analysis (e.g. Webb 2001:73-83, 152-162) and an awareness of the manner by which the text structures its purposeful, whole-of-life education in holiness. It is useful, therefore, to consider the Law as one does the Sermon on the Mount (Goldingay 2009:30), namely a depiction of a life lived with God, kin, community and creation.

Israel's political economy, for instance, was to be markedly dissimilar, in structure and process, from the social stratification and centralised power of Egypt, from whence the Israelites were delivered. Deeply entrenched in the righteousness and justice of God, an appointed king 'like all the [surrounding] nations' (Deut. 17:14) was forbidden to emulate those autocracies by accumulating wealth and military or political power (vv. 16-20). Instead, he was to revere $\mathrm{YHWH}$ and consider himself equal with his fellow Israelites (vv. 18-20).

When considered paradigmatic, the Law provides both a normative framework and a model (Wright 1992:227-229). Indeed, although the concrete specificity of the Law is pertinent to the historical-cultural context of a theocratic state, the theological and ethical norms therein have demonstratively been interpreted and appropriated to serve the post-exilic remnant (e.g. Neh. 5, 10) and the early church (e.g. Acts 4:32-37).

\section{The prophets}

The prophets' scathing denunciation of socio-economic injustice and anthropocentric cultic practice provides an indisputable critique of society's broken relationship with YHWH. By analysing the Prophetic Literature one may ascertain that which God most seeks to transform and the values that he deems most essential to uphold (e.g. Gossai 2006:251-307). Although prophetic critique necessarily retains historical-cultural specificity, its message is largely consistent despite a temporal scope encompassing much of Israelite history. Its overarching lessons thus aptly complement the concreteness of the Torah.

Furthermore, Brueggemann (2001) articulates the means by which prophetic criticism is enacted. The process incorporates an acute recognition of the gross disparity between ideology and praxis and participation in God's pain as expressed by an outpouring of grief, lament or anguish, as opposed to anger and indignation. The prophet thus exposes the systemic relational brokenness and facilitates the public expression of 
fear so as to infiltrate the mainstream numbness and selfdeception. Significantly, asserts Brueggemann, prophetic criticism is paired with the proclamation of hope, yearning and renewal in $\mathrm{YHWH}$ by which to penetrate the despair. The Prophetic Literature thus demonstrates the elicitation of God's priorities with reference to the contemporary situation and also the proper manner by which this may be addressed.

\section{Wisdom}

From the joyful song of Solomon's lovers tempered by the perturbed disquiet of Ecclesiastes, from proverbs embracing secular ANE wisdom counterbalanced by the centrality of YHWH in the psalms, the Wisdom texts offer a wide-ranging commentary of life. The ways in which these varied texts train the people of God in social critique are highlighted below using two pertinent examples. Firstly, both Job and Ecclesiastes present an overt criticism of the prosperity doctrine and the pursuance of meaning independent of God, guiding readers and listeners to recognise the range of potential ideological pitfalls and the ease with which one may plunge into faulty thinking. Secondly, the bold truisms found within Proverbs extend insights that are accurate in certain settings but are not automatically universal (e.g. Prov. $14: 4,11,19,22)$. This challenges God's people to examine the situations to which these lessons may be applied.

\section{Conclusion}

The Hebrew Bible is the inspired Word of God. It teaches that which he determines should be known. The text provides a structured learning programme in order that the people of God, in a relationship with and an identity in him, may know him and walk in his way of righteousness and justice. Thus, the Hebrew Bible itself teaches its readers and listeners how to learn. It provides the necessary instruction to enable interpretation and application of the lessons therein. In heeding this training, Christians are well placed to advance YHWH's missional purpose and appropriate biblical social transformation.

\section{Acknowledgements}

The author would like to thank Mary J. Evans for sharing her wisdom and insights on narrative texts.

\section{Competing interests}

The author declares that she has no financial or personal relationships that may have inappropriately influenced her in writing this article.

\section{References}

Bauckham, R., 2011, The Bible in politics: How to read the Bible politically, 2nd edn., SPCK, London.

Brueggemann, W., 2001, The prophetic imagination, 2nd edn., Fortress Press, Minneapolis.

Colless, B.E., 1970, 'Divine education', Numen 17, 118-142. http://dx.doi. org/10.1163/156852770X00135

Collinson, S.W., 2006, Making disciples: The significance of Jesus' educational methods for today's church, Wipf \& Stock, Eugene.

Fox, M.V., 1994, 'The pedagogy of Proverbs 2', Journal of Biblical Literature 113, 233-243. http://dx.doi.org/10.2307/3266512

Geisler, N.L., 2010, Christian ethics: Contemporary issues and options, 2nd edn., Baker Academic, Grand Rapids.

Goldingay, J., 1987, Theological diversity and the authority of the Old Testament Eerdmans, Grand Rapids.

Goldingay, J., 2009, Old Testament theology, vol. 3, Israel's life, IVP Academic, Downers Grove.

Gossai, H., 2006, Social critique by Israel's eighth-century prophets: Justice and righteousness in context, Reprint edn., Wipf \& Stock, Eugene.

Hauerwas, S., 2010, A community of character: Toward a constructive Christian socia ethic, University of Notre Dame Press, Notre Dame.

Kim, K., 2004, 'India', in J. Parratt (ed.), An introduction to third world theologies, Cambridge University Press, Cambridge. http://dx.doi.org/10.1017/CBO9780511801587.003

Kohlberg, L., 1981, Essays on moral development, vol. I: The philosophy of moral development, Harper \& Row, San Francisco.

Nasuti, H.P., 1986, 'Identity, identification, and imitation: The narrative hermeneutics of biblicallaw', Journal of Law and Religion 4, 9-23. http://dx.doi.org/10.2307/1051217

Webb, W.J., 2001, Slaves, women and homosexuals: Exploring the hermeneutics of cultural analysis, Inter-Varsity Press, Downers Grove.

Wood, D., Bruner, J.S. \& Ross, G., 1976, 'The role of tutoring in problem solving', Journal of Child Psychology and Psychiatry and Allied Disciplines 17, 89-100. http://dx.doi.org/10.1111/j.1469-7610.1976.tb00381.x

Wright, C.J.H., 1992, 'The ethical authority of the Old Testament: A survey of approaches. Part II', Tyndale Bulletin 43, 203-231.

Wright, C.J.H., 2004, Old Testament ethics for the people of God, Inter-Varsity Press, Nottingham.

Wright, C.J.H., 2006, The mission of God: Unlocking the Bible's grand narrative, IVP Academic, Downers Grove. 